This item was submitted to Loughborough's Research Repository by the author.

Items in Figshare are protected by copyright, with all rights reserved, unless otherwise indicated.

\title{
Ultrasound propagation in concentrated random dispersions of spherical particles: thermal- and shear-mediated contributions to multiple scattering
}

\section{PLEASE CITE THE PUBLISHED VERSION}

http://dx.doi.org/10.1121/1.4920369

\section{PUBLISHER}

(C) Acoustical Society of America

\section{VERSION}

AM (Accepted Manuscript)

\section{PUBLISHER STATEMENT}

This work is made available according to the conditions of the Creative Commons Attribution-NonCommercialNoDerivatives 4.0 International (CC BY-NC-ND 4.0) licence. Full details of this licence are available at: https://creativecommons.org/licenses/by-nc-nd/4.0/

\section{LICENCE}

CC BY-NC-ND 4.0

\section{REPOSITORY RECORD}

Pinfield, Valerie J., and D. Michael Forrester. 2015. "Ultrasound Propagation in Concentrated Random Dispersions of Spherical Particles: Thermal- and Shear-mediated Contributions to Multiple Scattering". figshare. https://hdl.handle.net/2134/18583. 


\title{
Ultrasound propagation in concentrated random dispersions of spherical particles: thermal- and shear-mediated contributions to multiple scattering
}

\author{
Valerie J Pinfield, D Michael Forrester \\ Chemical Engineering Department, Loughborough University, UK
}

Ultrasonic techniques offer advantages for process monitoring for dispersions of colloidal or nano particles; such materials occur in a wide variety of process industries. However, the application of ultrasonic techniques has been limited by the inaccuracy of ultrasonic propagation models used to interpret the measurements (typically attenuation spectra). Multiple scattering models, such as the Lloyd and Berry model (Proc Phys Soc London, 1967 (91) 678), have been used with great success in relatively dilute colloidal dispersions, but fail for higher concentrations, smaller particles, and low frequencies, primarily due to the neglect of thermal- and shear-mediated effects. We present a modified multiple scattering model that includes these thermal- and shear-wave contributions and explore their significance. The model develops work by Luppé, Conoir and Norris (J Acoust Soc Am, 2012 (131) 1113) for compressional, thermal and shear wave propagation. We identify the dominant scattering contributions for emulsions (Pinfield, J Acoust Soc Am, 2014 (136) 3008) and suspensions and develop analytical forms for them. Numerical calculations demonstrate the contribution of the additional multiple scattering effects to the compressional wave speed and attenuation through the emulsion or suspension. The calculations are compared with previously published experimental data. 